CORRIGENDUM

\title{
Corrigendum: CaMKII: a biochemical bridge linking accumbens dopamine and glutamate systems in cocaine seeking
}

Sharon M Anderson, Katie R Famous, Ghazaleh Sadri-Vakili, Vidhya Kumaresan, Heath D Schmidt, Caroline E Bass, Ernest F Terwilliger, Jang-Ho J Cha \& R Christopher Pierce

Nat. Neurosci. 11, 344-353 (2008); published online 17 February 2008; corrected after print 1 April 2008

In the version of this article initially published, Thr286 was substituted for Ser831 in the second sentence of the concluding paragraph. The sentence should read: "The reinstatement of cocaine seeking is also associated with an increase in GluR1 phosphorylated on Ser831, a CaMKII phosphorylation site, and enhanced cell-surface expression of GluR1-containing AMPA receptors in the accumbens shell." The error has been corrected in the HTML and PDF versions of the article. 